\title{
A Study on the Uses of Social Networking Sites on Young Adults to Infer on the Different Types of Users
}

\author{
Jesus Milton Rousseau S. ${ }^{1}$, Dr. K. Puttaraju ${ }^{2}$, \\ ${ }^{1}$ Research Scholar, Department of Communication, Bangalore University \\ ${ }^{2}$ Professor (Retd.), Department of Communication, Bangalore University
}

\begin{abstract}
Social Networking Sites (SNSs) are used for multiple purposes and have become an essential part of our everyday activities. The divergent uses of SNSs make SNSs as an interactive platform for interpersonal connectivity and social enhancement through social communication. The study investigates on the frequently used SNSs and uses of SNSs among the young adults in Bangalore city to infer on the different types of users. The research study used survey method to collect information from 120 young adults (20-35 years) across Bangalore city. The study found that Facebook, LinkedIn, Twitter and Google+ were the frequently used SNSs. The study identified 32 uses of SNSS, from which 30 different types of SNSs' users were inferred, they are: Networkers, Chatters, Buddy's Info Seekers, Content Makers, Professors, Hobby Vicars, Reporters, Preachers, Frequent Communicators, Status Stealers, Self-Broadcasters, Philosophers, Pet Lovers, Attractive Posters, Best Wishers, Attention Grabbers, Vernacular Posters, Like Likers, Responders, Silent Observers, Social Stars, Players, Endorsers, Dedicated Followers, Daters, Feature Lovers, Career Seekers, Learners, Political Campaigners and Info Pilfers. The divergent uses of SNSS in the present study reinforce SNSs as the preferred choice of communication tool, especially for social communication in urban areas.
\end{abstract}

Keywords: Social Networking Sites, Facebook, LinkedIn, Twitter, Google+

\section{Introduction}

Social networking sites (SNSs) have grown beyond time pass activity and become a significant \& useful, but addictive activity in our daily lives. Today, SNSs' users are more pro-active participants by using it almost 24/7 for some of their favourite activities like chatting, commenting, liking, posting new content, tagging photos, following celebrities, etc. With higher levels of user engagement, social networking sites have become a significant means of communicating, networking, building and maintaining personal or business relationships, etc.

Childnet International Research Report, defines SNSs as, "Social networking services can be broadly defined as Internet- or mobile-device based social spaces designed to facilitate communication, collaboration and content sharing across networks of contacts." SNS allows its users to become content creators and content consumers at the same time, thus allowing instant participation, sharing of thoughts or information and personalised communication. Further the report adds, "Social networking services are changing the ways in which people use and engage with the Internet and with each other. Young people, particularly, are quick to use the new technology in ways that increasingly blur the boundaries between online and offline activities. Social networking services are also developing rapidly as technology changes with new mobile dimensions and features." (Childnet International Research Report, 2008) Lately, people are so addicted to their favourite social networks, that it is consuming even their real life or offline activities' time.

There are hundreds of SNSs available in the world. The top 5 social networking sites in the world, based on the Alexa and Quantcast ranking, are: Facebook, Twitter, LinkedIn, Pinterest and Google+. With a plethora of social networking sites available, people can choose their favourite SNSs based on the best features available and where their maximum numbers of friends are members to build their own personal socialising network.

\section{Purpose}

SNSs are used for multiple purposes with new features being introduced frequently. With the gigantic worldwide growth of SNSs with new features, it is becoming imperative to study on the uses of SNSs and categorise them into different kinds of users. Earlier studies have given broad classification on different types of SNSs users, but SNSs are multi-purpose sites hence can't be classified broadly, as there are many divergent users across the world. Hence, this study finds out and portrays the different ways in which people use social networking sites and based on the results tries to identify a detailed categorisation of the different types of SNSs users. Also the purpose of the study is to identify the frequently used SNSs. 
The study helps to identify the different types of SNSs users and to predict the participating level and objective of different users which can be used by marketing professionals to enhance their success rate of digital marketing campaigns. Also, the findings can help in customizing the SNSs design based on user types, for existing and yet-to-be launched SNSs.

\section{Literature Review}

Earlier studies have focussed on the uses of SNSs and types of SNS users separately; hence the review of literature is divided into 2 sections, namely: Studies on uses of SNSs and Studies on types of SNSs' users.

\subsection{Studies on Uses of SNSs}

Few of the earlier researchers have examined the uses of SNSs. Danah Boyd in one of her early studies found that teenagers joined MySpace because that's where their friends were, also teenagers don't know what they do on the site, they just hang out. The study stated, "Teens join MySpace to maintain connections with their friends....... Teens often turn to sites like MySpace for entertainment; social voyeurism, passes time while providing insight into society at large.” (Boyd, 2007) Aaron Smith from Pew Internet \& American Life Project in his research on "Why Americans use social media", found that Americans use social media tools to connect with family members and friends (both new and old), and to connect with old friends they've lost in touch. Other minor uses include: connecting around a shared hobby or interest (14\%), making new friends (9\%), reading comments by public figures (5\%) and finding potential romantic partners (3\%). (Smith, 2011) Further, Kaveri Subrahmanyam, Stephanie M. Reich, Natalia Waechter and Guadalupe Espinoza explored on the emerging adults' use of social networking sites for communication and stated that emerging adults use social networking sites to interconnect with others like staying in touch with their friends as well as their family members and relatives. They spent much of their time on social networking sites by reading comments, writing comments, and responding to comments/messages. Another top activity was browsing the pages/profiles of their friends. (Subrahmanyam, 2008)

Manzoor Ali Mirani also found that students use SNSs to find old friends, maintain their existing offline relations, pass time \& be entertained, while some are likely to develop new relationships. The study results also suggested that for students, online social networking sites are the means to strengthen their connections with offline networks. (Mirani, 2011) On the similar lines, Salim Said Ali Al kindi and Saadat M. Alhashmi discovered that students used SNSs for finding information and sharing news, while, other students who didn't use it was because of their lack of experience, time, and IT skills. (Al kindi, 2012) Andraws Swidan, Hasan Al-Shalabi, Mustafa Jwaifell, Arafat Awajan and Adnan Alrabea's research on use of SNSs in Jordanian Universities found that Jordanian Universities' students use social networking sites like Facebook, Twitter, Yahoo! Buzz and Windows Live intensively for academic purpose. (Swidan et. al, 2013)

Another study by Mujeeb-ur-Rehman Abro, Li Zhenfang, Abdul Razaque Chhachhar and Syed Awais Hassan Gillani examined the usage pattern of SNSs and the adoptability of the users, from a large university in Pakistan and found that SNS users logged in at least once a day and were bridging the social capital by adding strangers; hence majority of the students didn't know their Facebook friends personally. (Abro, 2014) Also a study by Tamyra A. Pierce discussed on use of social networking sites to talk to strangers. (Pierce, 2006)

Few researches focused on the gender differences in usage patterns of SNSs. Nicole L. Muscanell and Rosanna E. Guadagno found men used social networking sites for networking, making new friends, and finding potential dates; while women used it for relationship maintenance. (Muscanell, 2012) Another similar study on Facebook by Güzin Mazman and Yasemin Koçak Usluel found females use Facebook for maintaining existing relationships, academic purposes and following agenda, while males use it for making new relationships. (Mazman, 2011)

\subsubsection{Facebook}

Some studies focussed on the uses of Facebook, one of the leading social networking sites in the world. Tiffany A. Pempek, Yevdokiya A. Yermolayeva, and Sandra L. Calvert found that $85 \%$ of college students used Facebook to communicate with friends, 9\% only used Facebook to make new friends and none used Facebook to keep in touch with their parents or any strangers. (Pempek, 2009) Also, Christy M.K. Cheung, Pui-Yee Chiu and Matthew K.O. Lee's study found most people use Facebook to get instant communication and connection with their friends. The study also highlighted five key values for using Facebook, they are: Purposive value, self-discovery, maintaining interpersonal interconnectivity, social enhancement, and entertainment value. Among the five values, social related factors (maintaining interpersonal interconnectivity and social enhancement) and entertainment value are found to be significant. (Cheung et al., 2011) Saleem Alhabash, Hyojung Park, Anastasia Kononova, Yi-hsuan Chiang and Kevin Wise's research explored in terms of 7 motivations to use Facebook (Social connection, shared identities, photographs, content, social investigation, social network surfing, and status updates) to predict the intensity of Facebook use and content generation 
behaviours on Facebook. The study found that motivation to use Facebook for posting and viewing status updates was the strongest predictor of Facebook intensity, whereas motivation to view and share photographs was the strongest predictor of content-generation behaviour on Facebook. Also, the study showed that the highest rated motivation to use Facebook was social connection. (Alhabash et al., 2012)

\subsubsection{Indian Studies}

Mohamed Haneefa K. and Sumitha E. in their study on uses of SNSs by the students of Calicut University, found that majority of the students used SNSs for friendly communication, followed by academic purposes, with their real names and photos. (Haneefa, 2011) Another research on Sikkim University Students by Neeraj Kumar found that majority of the Sikkim University students used SNSs for academic purpose, followed by friendly communication and making friendship. (Kumar, N., 2012)

Manjunatha S. in his research on the usage of Social Networking sites among the college students in India revealed that almost half of the students (48\%) use social networking sites to maintain existing friends/relationships, followed by using it for finding new friends, and the least (only 3\%) use it for dating purposes. Also, male students use social networking sites more than female students. The study also stated that the main purpose of using social networking sites is for messaging and chatting. (Manjunatha, 2013)

Few of the studies highlighted use of SNS by a particular section of users like the research scholars. Dr. KP Singh and Malkeet Singh Gill's study on use of SNSs by the research scholars of Guru Nanak Dev University, Amritsar found that the main purpose of using SNSs is interacting with family and friends followed by 'to find useful information'. The study concluded that several features of the SNSs such as profile surfing, posting of messages, photos, videos, making friends, join communities etc. are the medium by which scholars keep updates and share professional and personal information. (Singh \& Gill, 2011) Another study by Margam Madhusudhan, showed that research scholars of University of Delhi preferred social networking site Facebook and ResearchGate for academic use. Most of the respondents used social networking sites for 'lurking', while few used it for promoting their own research. Cyber-bullying and privacy concerns were expressed by some research scholars, while majority of them maintained using social networking sites may be a waste of time. (Madhusudhan, 2012)

\subsection{Studies on Types of SNSs' users}

In 2006, Nielson's research suggested a 90-9-1 rule on social media and user generated content; in which $90 \%$ are 'Lurkers' (read content but do not contribute), 9\% are Intermittent (sometimes contribute) and $1 \%$ are Heavy contributors (active users). (Nielsen, 2006) Later, Ofcom's qualitative research report identified and classified 5 types of SNSs users, they are: Alpha Socialisers - a minority of users who use SNSs for flirting and meeting new people; Attention Seekers - are few people who crave for attention and comments from others by posting photos of themselves and customising their profiles; Followers - are many SNSs users who joined SNSs to keep up with what their peers were doing; Faithfuls - are many people who typically use SNSs to rekindle old friendships, often from school or university; and Functionals - are a minority of users who singlemindedly use SNSs for a particular purpose (e.g. pursuing interests or hobbies). (Ofcom, 2008)

Josh Bernoff and Charlene Li, authors of Groundswell, Forrester in their research on Social Technographics identified 6 types of online social media users, they are: The Creator - person who publishes blog posts or web pages, upload videos/images/audio and share content online for the world to see; The Critic person who responds to content posted by others, they also post ratings and reviews of products and services, comments on blogs and participate in online forums and contributes to/edit articles in a wiki; The Collector person who organizes content for themselves or others using RSS feeds, social bookmarking (ex: Digg), tags and photo or page tagging; The Joiner - person who joins social networking websites like Facebook and Twitter and maintains multiple profiles; The Spectator - most common type of person, who are blog readers, videos viewers (ex: YouTube), podcast listeners, reads online forums, and frequently searches for user reviews and ratings; The Inactive - person who is online but in no way participates in any form of social media, usually they don't post anything or read anything which is user-generated content. (Bernoff, 2008; Bernoff \& Li, 2009) Later, in 2010, Bernoff added one more type (the seventh type) called "Conversationalists" - person who updates their status on social media sites such as updating their status on Facebook or tweeting from Twitter. They voice their opinions to other consumers and businesses using vehicles like SNSs. (Bernoff, 2010)

Adrian Chan, UX lead and manager at deloittedigital.com in his work on Social Media Personality Types identified 11 types of social media users, they are: Status seeker, Critic, Socializer, Em-cee, Lurker, Buddy, Creator, Pundit, Rebel, Officiator, Harmonizer. (Chan, 2008) Melonie, Dodaro from TopDogSocialMedia, a Social Media Marketing Agency, cited 10 types of Social Media users, they are: The Listener (an active social media user but prefers to fly under the radar), The Activist (a person who strives to have their voice heard to make a difference), The Spammer (type of person who sends weekly promotional messages directly to others inbox, since they are his Facebook friends), The Passionista (users who focus their 
time on exploring and sharing their passion with others online), The Social Butterfly (users who gets tagged in pictures with others and shows how popular they are on their Facebook wall!), The Troll (users who manage to give downright hate speech, no matter how sensitive or irrelevant the issue), The Teacher (users who love to share their knowledge through "quality content"), The Early Adopter (users who have moved on to the next new social service that one might hear after 18 months), The Black Booker (is a true relationship builder, as a means to communicate with other people), The Family Man (users who fell in love with social media the moment they realized they could keep in touch with their family members from every corner of the world). (Dodaro, 2013)

Brandtzæg and Heim in their research study on social networking sites users', collected data using survey method from 5,233 respondents in four major Norwegian SNSs and found five distinct user types: sporadic, lurkers, socialisers, debaters and actives. (Brandtzæg and Heim, 2011)

\subsubsection{Facebook}

Ibnlive website posted 16 types of Facebook users, they are: The "Lurker" - Never posts anything or comments on the post, but reads everything; The "Hyena" - Doesn't ever really say anything, just LOLs and LMAOs at everything; "Mr/Ms Popular" - this type of user has 4367 friends for NO reason; The "Gamer" Plays Words with Friends, Mafia Wars, Bakes virtual cakes and stuff, etc.; The "innocent" - Every post makes reference to God or Jesus; The "Thief" - Steals status updates; The "Cynic" - Hates their life, as evidenced by the sombre tone in all of their status updates; The "Collector" - Never posts anything either, but joins every group and becomes fans of the most random stuff; The "Promoter" - Always sends event invitations on things that others might ultimately delete or ignore; The "Liker" - Never actually says anything, but always clicks the "like" button; The "Hater" - Every post revolves around someone hating on them, and they swear people are trying to ruin their life; The "Anti-Proof reader" - This person would benefit greatly from spell check, and sometimes feel bad for them because we don't know if they were typing fast, or really can't spell; "Drama Queen/ King" - This person always posts stuff like "I can't believe this!"; "Womp Womp" - This person consistently tries to be funny, but never is; The "News" - Always updates on what they are doing; The "Rooster" - Feels that it is their job to tell Facebook "Good Morning" every day. (Ibnlive, 2013)

Casti in Mashable shares 9 types of Facebook users, they are: The Stalker - Never lets go of an ex. Logs in 14x a day. Logging on to other people's Facebook profiles to stalk their friends; The Baby boomer Their favourite activity is commenting on their kids' wall posts; The Newbie - Photo is a selfie from their Cell phone and liking or commenting everything; The over-sharer - Posts status updates about everything; The Brand promoter - only shares their company's news; The Fearful user - they keep their profile on lock down, their favourite activity is inventing false names for maximum camouflage; The Curator - they put the 'viral' in Videos, like sharing cute cat photos, etc; The Gamer - Interacts only through the medium of Facebook games; The Non-User - Registering was itself hard enough and now we can't expect them to log on. (Casti, 2013)

The Doozyden, an online media site, identified 25 types of Facebook users, they are: The Broadcasters - These people would let the world know everything they do; The Heartbreakkids - portray that they are the epicentre of all the sorrows in this world and always post painful status and blame a person without revealing the person; The Velagamers - they try out different games on Facebook and they consider everyone alike; The Selfiedelfies - These people consider themselves very photogenic, they change their profile pictures very frequently; The Photofumblers - users who have a DSLR and show pictures of them with DSLR's, pictures of birds, sky, sun, landscape, etc.; The Soccersuckers - they keep updating about club matches - soccer; The Mahagyanis - these people are the source of all the current affairs and political environment; The Tagparasite these people just try to obtain likes by tagging others; The Status-chor - these people always post the status by stealing it from the walls of others; The LoLvas and LoLvis - these people rarely update any status they just share others status, 'LoL' is their most loved word and end up writing 'Lol' everytime; The \#hashbashers these people don't need description they are fond of making everything public; The Songhonkers - these people are listening to a track and they update it on Facebook; The prettylikebankers - this category goes to all the pretty ladies, the likes on their pictures ranges from 200-1000 and comments ranges from 100-500; The Locallingolites - these people have so much love about their local language that they keep posting their status in local language; The Atibhavuks - these people get very emotional on Facebook, they post eye-watering status for friends and relatives; The Adventurers - they pose themselves as highly adventures and happy being on earth; The Humourdisasters - these people try their best to be humorous but they end up terribly; The CRockstar these people want to be Rockstar just by posting their pics in rockstar look with a guitar in hand; The Creativegems - these people are very creative, they post original stuffs like poems, etc.; The Ghumshudas these people just make a Facebook account and then get so busy in their life that they forget about it; The Dumbpromoters - just share posts like this biscuit has worms and they don't investigate it before sharing; The Newscorrespondents - They are really fast in updating breaking news on Facebook; The Marriagecorrespondents - would give complete update of every events like mehndi, sangeet, baraat, reception; 
A Study on the Uses of Social Networking Sites on Young Adults to Infer On the Different...

The Airportlovers - these people have special connection with airports, they get all the feelings only at International Airports; The Poliovictims - these people just want to show that they are cool. (Doozyden, 2014)

\subsubsection{Twitter}

Guy Kawaski, Advisor, Motorola Mobility found 6 Twitter Types, namely: a) The Newbie - joins Twitter curiously for less than three months and thinks it's all about lifestreaming. These people quickly progress to a different type of use or abandon Twitter when no one pays attention to them. b) The Brand - "What can I get away with?" The Brand balances the tension between using Twitter as a marketing tool and socially engaging people so as not to appear to be using Twitter as a marketing tool. c) The Smore. "What's in it for me?" The Smore (social media whore) sees Twitter primarily as a self-promotion tool to get something from people. d) The Bitch. "What can I complain about?" is usually an angry man who envies people who generate content. They can be briefly amusing in a "shock jock" kind of way, but their bark is greater than their bite, and their bite is greater than their insight. e) The Maven - "What's interesting in my niche?" The Maven is an expert in a field such as recruiting, marketing, or web design. If a user is interested in their field, following them is a rich, rewarding, and time-saving experience. f) The Mensch - "How can I help?" Mensches are few and far between. They lurk in the background until people need help and then they either know, or know how to find, the answer. They are seldom well-known or highly followed, but they save tons of time and effort when someone wants to know something. (Kawaski, 2009; Male, 2009)

Minter Dial, president and founder of The Myndset, in his presentation on 7 Archetypes of Twitter Accounts revealed: a) The Social Star - The Social Star has a big following by providing consistently strong content and yet follows others and interacts with them democratically. b) The Butterfly -interacts with all types of users, throughout the day and is socially engaged and active and likely delivers or redistributes good content. c) The Distant Star - is a celebrity who is not much of a social animal. The Distant Star is likely more comfortable offline and has influence, but depending on his/her level of interaction with other users, has a tendency to be more of a recluse, preferring his/her privacy. d) The Private Eye - users are 'protected' meaning the user needs to approve you as a follower, though they are active than the typical user in terms of number of updates. e) The Cycler - Has a lot of followers, but is typically also following a large number. The Cycler has a dedicated strategy of following people and will only keep on following if the user follows back. f) The Listener - Twitter accounts that never emit a single update/tweet. This does not mean that the account is inactive; there are those who have reserved the username (handle). They may tweet on occasions. g) The Egghead - a newbie to Twitter, the profile is incomplete, the number of tweets will be negligible, and the number of followers is decidedly anaemic. (Dial, 2013)

Steve Faktor in Forbes claims 10 types of Twitterers, they are: Undead, Protector, Chirper, Fan, Networker, Scouts, Stars, E-lebrities, Media Co and Organizations. (Faktor, 2013) Also, Pickering posted 10 types of Twitter Users in the Huffington post, they are: Egg, Lurker, Contester, Retweeter, Bot, \#TeamFollowBack, Celebrity, "Guru", Business and The Best of the Rest. (Pickering, 2014)

\subsubsection{LinkedIn}

Anderson Analytics conducted a study in partnership with LinkedIn.com using predictive analytics and released 4 types of LinkedIn users, they are: a) "Savvy Networkers" - users who are likely to have started using social networking earlier than others, are more tech savvy, and more likely to be active on other SNS sites like Facebook. Savvy Networkers have the most connections and are more likely than other segments to use LinkedIn for a wide variety of purposes other than job searching. b) "Senior Executives"- are somewhat less tech savvy and is using LinkedIn to connect to their existing corporate networks. They have power jobs which they are quite content with, and are likely to have been invited by a colleague and then realized how many key contacts were on the site and started building connections. c) "Late Adopters" - are likely to have received numerous requests from friends and co-workers before deciding to join. They are somewhat less tech savvy and are careful in how they use LinkedIn, tending to connect only to close friends and colleagues and have the fewest number of connections. d) "Exploring Options" - may be working, but are open and looking for other job options, perhaps in part because they have the lowest average personal income. They are fairly tech savvy and use SNS for both corporate and personal interests. (Anderson Analytics, 2008)

\section{Objectives}

1. What are the frequently used SNSs among young adults in Bangalore?

2. What are the most popular uses of SNSs among young adults in Bangalore?

3. To identify and categorise the different types of SNSs users. 


\section{Methodology}

The present study is exploratory in nature. The descriptive survey method was used in the present research, as it is considered as the most effective method to collect information across a region by saving time and money. Also, in survey method, the respondents are assured of their confidentiality, hence majority of the responses are true.

A multi-page with multi-item detailed questionnaire was prepared, based on the review of the past literature and by subjective content analysis of 50 users' profiles \& activities in various SNSs. The questionnaire had both open-ended and close-ended questions. The close-ended questions used Likert Rating scale to determine the usage patterns of SNSs and level of participation of the respondents. The 5-point Likert scale ranged from "Never" to "Always" (Never, Rarely, Sometimes, Often or Always).

The questionnaires were administered face-to-face randomly on 120 young adults' (i.e. 20 - 35 years of age) in Bangalore city.

The percentage analysis along with the mean scores and SD was used to recognize the level of participation of the respondents for each of the uses identified, which helps in inferring the different types of users.

\subsection{Demographic profile}

\section{Analysis and Discussion}

The sample size for the present study was 120 young adults aged between 20-35 years. Gender wise the sample had more number of males $(53.33 \%, \mathrm{n}=64)$ than females $(46.67 \%, \mathrm{n}=56)$. Age group wise the sample had $46.67 \%(n=56)$ belonging to the age group of $30-35$ years, $40 \%(n=48)$ belonging to $26-30$ years and $13.33 \%(\mathrm{n}=16)$ belonging to $20-25$ years. Among the sample majority had completed their post graduation $(66.67 \%, \mathrm{n}=80), 26.67 \%(\mathrm{n}=32)$ had completed their graduation and $6.67 \%(\mathrm{n}=8)$ had completed their Doctorate or M.Phil. Also $80 \%(n=96)$ of the sample were working in various industries and only $20 \%(n=24)$ were not working or studying.

\subsection{Internet and SNSs Usage}

Among the sample $33.33 \%(n=40)$ spent 3-5 hours per day browsing the web, another $33.33 \%(n=40)$ spent 1-3 hours, $20 \%(\mathrm{n}=24)$ spent 5-7 hours and $6.67 \%(\mathrm{n}=8)$ spent less than an hour, surfing the web per day, while another $6.67 \%(\mathrm{n}=8)$ surfed more than 7 hours. One of the respondents had mentioned that she browsed the web 10-12 hours per day. Also, majority of the respondents $(93.33 \%, \mathrm{n}=112)$ accessed internet from their smart phones or mobile phones.

\subsection{Frequently used SNSs}

The frequently used SNSs in Bangalore by the young adults were Facebook, Twitter, Google+ and LinkedIn. All the respondents i.e. 100\% $(\mathrm{n}=120)$ used Facebook, $80 \%(\mathrm{n}=96)$ used LinkedIn, 66.67\% $(\mathrm{n}=80)$ used Twitter and only $40 \%(\mathrm{n}=48)$ used Google+ frequently; also $6.67 \%(\mathrm{n}=8)$ used other SNSs like Pinterest, Tumblr. (See Fig. 1)

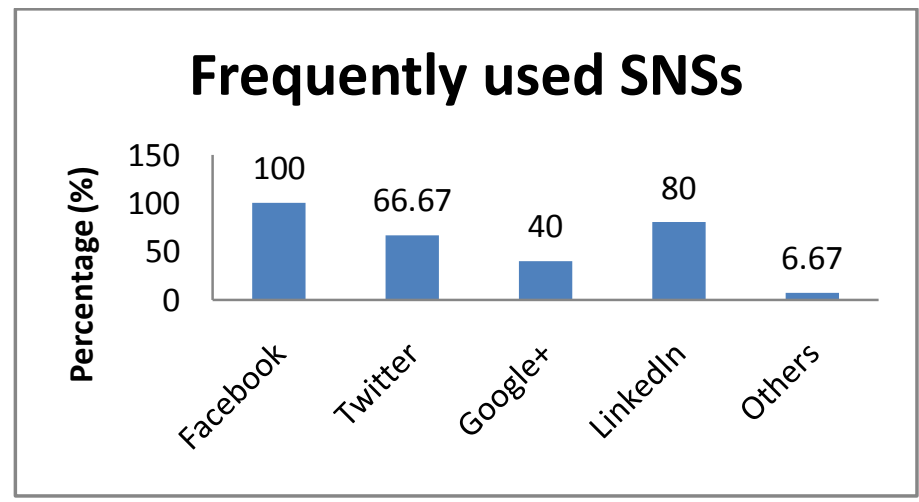

Figure 1: Frequently used SNSs

Among the Social Networking Sites, $66.67 \%(\mathrm{n}=80)$ of respondents stated Facebook was their favourite SNSs, followed by $20 \%(\mathrm{n}=24)$ for Twitter and $13.33 \%(\mathrm{n}=16)$ for LinkedIn. 


\subsection{Time Spent on SNSs}

Most of the respondents i.e. $44.63 \%$ of the respondents used SNSs for less than 30 minutes per day, followed by $25.5 \%$ using it for 30 minutes to 1 hour per day. While 8.5\% used SNSs 1-2 hours and 2-3 hours each respectively and $4.25 \%$ used SNSs 3-4 hours, 5-6 hours and 6-7 hours each respectively.

\subsection{Popular uses of SNSs \& inference on the type of Users}

SNSs were regularly used for various reasons by young adults in their daily lives. (see TABLE 1)

Most of the online users accessed SNSs to find old friends, new friends, colleagues; 20\% ( $n=24)$ of the respondents always used and $46.67 \%(n=56)$ often used and another $20 \%(n=24)$ sometimes used SNSs for the same. Similarly, 33.33\% ( $\mathrm{n}=40)$ often used and 26.67\% $(\mathrm{n}=32)$ sometimes used SNSs to build new contacts/make new friends. But $33.33 \%(\mathrm{n}=40)$ claimed they rarely used SNSs to build new contacts/make new friends. Hence, these users can be termed as "Networkers" i.e. they use SNSs extensively to find old friends/make new friends, colleagues, build new contacts, etc to achieve their goal of widening their network of friends.

SNSs is the primary choice of tool for chatting; $13.33 \%(n=16)$ of the respondents always used, $33.33 \%$ $(\mathrm{n}=40)$ often used and another $40 \%(\mathrm{n}=48)$ sometimes used SNSs for chatting with friends or family members. These users can be named as "Chatters" as they use SNSs constantly for chatting/messaging with their friends.

Majority of the respondents used SNSs to check what their friends have posted; 33.33\% ( $\mathrm{n}=40$ ) often used and 20\% ( $\mathrm{n}=24)$ always used and another $33.33 \%(\mathrm{n}=40)$ sometimes used it for the same. These users can be classified as "Buddy's Info Seekers", as these users are constantly interested in checking information pertaining to their friends on SNSs via updates or posts on what their friends are doing, where they are going, etc.

SNSs are platforms to create and share original content; hence many users create blogs, videos etc and share on the SNSs. $26.67 \%(\mathrm{n}=32)$ of the sample often used and another $26.67 \%(\mathrm{n}=32)$ sometimes used SNSs to create new content and share on SNSs. These users can be titled as "Content Makers" as they are excited and thrilled about creating new or original content like blogs and videos and sharing it with their friends on SNSs.

Another set of users like to share their knowledge with others. $46.67 \%(n=56)$ of the respondents often used, $13.33 \%(\mathrm{n}=16)$ always used and 33.33\% $(\mathrm{n}=40)$ sometimes used SNSs to share their knowledge with others. These users can be termed as "Professors" i.e. users who love to share their knowledge with others via sharing quality content like interesting articles, how-to-do tips etc.

Majority of the respondents, $60 \%(\mathrm{n}=72)$ often and other $40 \%(\mathrm{n}=48)$ sometimes used SNSs to share their passion or hobby. These users can be termed as "Hobby Vicars" i.e. they like to flaunt their passion or hobby by sharing photos clicked by them, favourite music videos, movie reviews, travel destinations, adventure trip photos, favourite cooking recipes etc.

Also many SNSs users like to share news or 'breaking news' on their status messages. $33.33 \%(n=40)$ often, $13.33 \%(\mathrm{n}=16)$ always and $26.67 \%(\mathrm{n}=32)$ sometimes used SNSs to share latest news. These users can be classified as "Reporters" as they like sharing latest local or national or international news updates regularly. Majority of the times they do share real breaking news.

Some users like to be religious on SNSs. Among the sample only $13.33 \%(\mathrm{n}=16)$ respondents used SNSs sometimes to share religious views or verses, while $66.67 \%(n=80)$ never used it for the same. These users can be termed as "Preachers" i.e. users who share religious verses, quotes, views, pictures etc on their SNSs frequently.

Almost majority of the users, 25\% ( $\mathrm{n}=30)$ often, $6.67 \%(\mathrm{n}=8)$ always and $20 \%(\mathrm{n}=24)$ sometimes used SNSs for communicating on their whereabouts. These users can be termed as "Frequent Communicators", as they regularly update their status on what they're doing, where they are going, which restaurant they are visiting, etc.

Few users, $20 \%(\mathrm{n}=24)$ of the respondents sometimes like to share their friends status messages, while $33.33 \%(\mathrm{n}=40)$ of the sample never used it for the same. These users can be titled "Status Stealers", as they don't post any original status messages, but like to share others status messages on their Walls and sometimes portray it as their own status messages.

Most of the SNSs users are self obsessed; 15\% $(n=18)$ of the respondents always used, 20.83\% $(n=25)$ often used and 20\% ( $\mathrm{n}=24)$ sometimes used SNSs to post their 'Selfie' photos. These users can be named as "Self-Broadcasters" as they are obsessed with posting only their own "Selfie" photos and achievements.

Many users like to inspire their friends on SNSs; $19.17 \%(n=23)$ of the respondents often used, $6.67 \%$ $(\mathrm{n}=8)$ always used and $26.67 \%(\mathrm{n}=32)$ sometimes used SNSs to share inspirational quotes. These users can be termed as "Philosophers" as they share only inspirational quotes, pictures etc of great philosophers or writers or politicians.

Love for animals are also expressed explicitly by few users on SNSs. $13.33 \%(n=16)$ of the respondents sometimes used SNSs to share pictures of their pets, while $46.67 \%(n=56)$ rarely used it for the 
same. These users can be labelled as "Pet Lovers" i.e. users who like to post pictures of their own pets or animals, articles on animal welfare, pets adoption etc and share posts of animal welfare organisations frequently.

Majority of the users, 20\% $(\mathrm{n}=24)$ of the respondents always used, $13.33 \%(\mathrm{n}=16)$ often used, and 53.33\% ( $\mathrm{n}=64$ ) sometimes used SNSs to share interesting posts. These users can be termed as "Attractive Posters", as their main aim on SNSs is to share many interesting posts randomly to attract their friends or followers.

SNS are the best calendar organisers to remember all the friends' birthdays and anniversaries. Majority of the users, 73.33\% $(\mathrm{n}=88)$ of the respondents often used and 20\% $(\mathrm{n}=24)$ always used SNSs to wish their friends on their birthdays. These users can be labelled as "Best Wishers" as they don't miss to wish any of their friends' birthdays or anniversaries (work or marriage).

Many users, 30\% $(\mathrm{n}=36)$ of the sample often used, $8.33 \%(\mathrm{n}=10)$ always used and $13.33 \%(\mathrm{n}=16)$ sometimes used SNSs to share jokes. These users can be termed as "Attention Grabbers" i.e. these users use SNSs to post jokes, funny pictures/videos, etc to grab the attention of their friends and expect many people to like or comment on their posts.

Few users like posting in SNSs in their mother tongue language. In the sample, 33.33\% ( $\mathrm{n}=40)$ of the respondents rarely posted and $66.67 \%(\mathrm{n}=80)$ never posted in vernacular language. These users who like posting in vernacular languages can be termed as "Vernacular Posters", as they love posting their complete status messages or at least few words in their posts in vernacular languages like Tamil, Kannada, Hindi etc.

Majority of the users, $33.33 \%(n=40)$ of the respondents often used and $33.33 \%(n=40)$ sometimes used SNSs to like their friends posts. These users can be named as "Like Likers" as they love liking their friends or favourite stars or brands' posts, pictures, videos etc.

Some users like to respond to all their friends' posts. $26.67 \%(n=32)$ of the respondents sometimes responded to their friends posts, while $40 \%(\mathrm{n}=48)$ never used it for the same. These users can be termed as "Responders" as they respond to all their friends' messages, photos or videos by either liking it or commenting on it.

Few users, $6.67 \%(n=8)$ of the sample often used and 33.33\% $(n=40)$ sometimes used SNSs to read all the messages. This type of users can be labelled as "Silent Observers", i.e. they see all their friends' photos, read all their friends posts, comments, contents etc, but never respond to these posts by liking it or commenting on it. Silent Observers only absorb information.

Most of the users strive to have more number of friends and followers on SNSs. 16.67\% $(\mathrm{n}=20)$ of the sample often used, $12.5 \%(\mathrm{n}=15)$ always used and $26.67 \%(\mathrm{n}=32)$ sometimes used SNS to add many friends or followers. These users can be termed as "Social Stars", as they like to be most popular person among their friends with most number of friends and followers in all their SNS. In the sample, all the respondents had a Facebook account and it was found that $13.33 \%(n=16)$ had 1001-2000 friends, 20\% $(n=24)$ each had $801-1000$ and 401-600 friends respectively, 6.67\% ( $\mathrm{n}=8)$ had 601-800 friends, $26.67 \%(\mathrm{n}=32)$ had 201- 400 friends and only $13.33 \%(n=16)$ had less than 200 friends.

Games on SNSs are an addictive entertainment activity. In the study, $13.33 \%(\mathrm{n}=16)$ of the sample often played, 20.83\% $(\mathrm{n}=25)$ always played and 25\% $(\mathrm{n}=30)$ sometimes played games on SNSs. These users who regularly play games on SNSs E.g. Farmville, Candy Crush Saga on Facebook can be termed as "Players" as they are hooked on to these virtual games and send invites on SNSs to their friends to make them also play these SNSs games.

Some of the online users like to use SNSs to promote brands. $13.33 \%(n=16)$ of the respondents used sometimes and $6.67 \%(\mathrm{n}=8)$ often used SNS to promote brands. These users can be classified as "Endorsers", as they like to promote their self, their favourite brands, companies, music bands, etc. and even organise events.

Few users like only following their favourite stars, brands etc on SNSs; in the sample 20\% (n=24) of the respondents used it sometimes while $46.67 \%(n=56)$ never used it for the same. These users can be titled as "Dedicated Followers", as they follow all their favourite music bands, favourite brands, movies, restaurants etc on SNSs to get all the latest information on them.

Majority of the users, $73.33 \%(n=88)$ of the respondents claimed they never used and 20\% $(n=24)$ rarely used SNSs for dating purpose. But users who regularly use SNSs for dating purpose can be termed as "Daters", as they frequently use SNSs to flirt with the opposite sex members.

Many users, 23.33\% $(n=28)$ of the sample often used, $8.33 \%(n=10)$ always used and $13.33 \%(n=16)$ sometimes use Hash tags in all their posts to make it public. Similarly, $6.67 \%(\mathrm{n}=8)$ always used, another $19.17 \%(n=23)$ often used and $26.67 \%(n=32)$ sometimes used SNSs to tag themselves or their friends in the photos uploaded. These users can be labelled as "Feature Lovers" as they love experimenting and using all the latest features of SNSs extensively.

Majority of the respondents, $13.33 \%(n=16)$ of the respondents often used, $8.33 \%(n=10)$ always used and $40 \%(\mathrm{n}=48)$ sometimes used SNSs to seek jobs. These users can be termed as "Career Seekers", as they use SNSs like LinkedIn, Facebook groups extensively for job hunting and career orientation. 
A Study on the Uses of Social Networking Sites on Young Adults to Infer On the Different...

More than half of the users, $8.33 \%(n=10)$ of the sample always used, $6.67 \%(n=8)$ often used, and $40 \%(n=48)$ sometimes used SNSs for academic purposes. These users can be termed as "Learners" i.e. users who use SNSs mainly for academic purpose like sharing and asking questions/doubts or finding educational resources from their online friends or communities in SNSs.

Few SNSs users like to use SNSs for sharing their political thoughts. 6.67\% $(n=8)$ of the respondents sometimes used and $6.67 \%(n=8)$ often used SNSs to share their political views. These users can be titled as "Political Campaigners" as they use SNSs to aggressively propagate their favourite political party's views and ideologies.

Also, there are users who like to steal their friend's personal information. In the sample $93.33 \%$ $(n=112)$ of the respondents never used SNSs to steal their friends' data. But users who use SNSs to steal their friends' personal information or data can be termed as "Info Pilfers", as they steal personal data, contact information etc and use it for their personal gains. They are also referred to as hackers or stalkers.

Table 1: Uses of Social Networking Sites.

\begin{tabular}{|c|c|c|c|c|c|c|c|c|c|c|c|c|c|c|}
\hline \multirow{2}{*}{$\begin{array}{l}\text { Sl } \\
\mathbf{N} \\
\mathbf{0}\end{array}$} & \multirow[b]{2}{*}{ Uses of SNS } & \multicolumn{2}{|c|}{ Never } & \multicolumn{2}{|c|}{ Rarely } & \multicolumn{2}{|c|}{$\begin{array}{l}\text { Sometim } \\
\text { es }\end{array}$} & \multicolumn{2}{|c|}{ Often } & \multicolumn{2}{|c|}{ Always } & \multirow{2}{*}{$\begin{array}{l}\text { Tot } \\
\text { al }\end{array}$} & \multirow{2}{*}{$\begin{array}{l}\text { Me } \\
\text { an }\end{array}$} & \multirow[b]{2}{*}{ SD } \\
\hline & & $\%$ & $\mathbf{N}$ & $\%$ & $\mathbf{N}$ & $\%$ & $\mathbf{N}$ & $\%$ & $\mathbf{N}$ & $\%$ & $\mathbf{N}$ & & & \\
\hline 1 & $\begin{array}{l}\text { To find old friends, } \\
\text { new friends, } \\
\text { Colleagues: }\end{array}$ & 0.00 & 0 & $\begin{array}{l}13.3 \\
3\end{array}$ & 16 & $\begin{array}{l}20.0 \\
0\end{array}$ & 24 & $\begin{array}{l}46.6 \\
7\end{array}$ & 56 & $\begin{array}{l}20.0 \\
0\end{array}$ & 24 & 120 & $\begin{array}{l}3.7 \\
3\end{array}$ & $\begin{array}{l}0.9 \\
2\end{array}$ \\
\hline 2 & $\begin{array}{l}\text { To build new } \\
\text { contacts/ make new } \\
\text { friends }\end{array}$ & 6.67 & 8 & $\begin{array}{l}33.3 \\
3\end{array}$ & 40 & $\begin{array}{l}26.6 \\
7\end{array}$ & 32 & $\begin{array}{l}33.3 \\
3\end{array}$ & 40 & 0.00 & $\begin{array}{l}0 . \\
00\end{array}$ & 120 & $\begin{array}{l}2.8 \\
7\end{array}$ & $\begin{array}{l}0.9 \\
4\end{array}$ \\
\hline 3 & $\begin{array}{l}\text { To chat with } \\
\text { friends/family }\end{array}$ & 0.00 & 0 & $\begin{array}{l}13.3 \\
3\end{array}$ & 16 & $\begin{array}{l}40.0 \\
0\end{array}$ & 48 & $\begin{array}{l}33.3 \\
3 \\
\end{array}$ & 40 & $\begin{array}{l}13.3 \\
3 \\
\end{array}$ & 16 & 120 & $\begin{array}{l}3.4 \\
7 \\
\end{array}$ & $\begin{array}{l}0.9 \\
3\end{array}$ \\
\hline 4 & $\begin{array}{l}\text { To check what } \\
\text { friends have posted }\end{array}$ & 0.00 & 0 & $\begin{array}{l}13.3 \\
3 \\
\end{array}$ & 16 & $\begin{array}{l}33.3 \\
3 \\
\end{array}$ & 40 & $\begin{array}{l}33.3 \\
3\end{array}$ & 40 & $\begin{array}{l}20.0 \\
0\end{array}$ & 24 & 120 & $\begin{array}{l}3.6 \\
0\end{array}$ & $\begin{array}{l}0.9 \\
3\end{array}$ \\
\hline 5 & $\begin{array}{l}\text { To create new } \\
\text { content (like blogs, } \\
\text { videos) and share }\end{array}$ & $\begin{array}{l}13.3 \\
3\end{array}$ & 16 & $\begin{array}{l}33.3 \\
3\end{array}$ & 40 & $\begin{array}{l}26.6 \\
7\end{array}$ & 32 & $\begin{array}{l}26.6 \\
7\end{array}$ & 32 & 0 & 0 & 120 & $\begin{array}{l}2.6 \\
7\end{array}$ & $\begin{array}{l}0.9 \\
5\end{array}$ \\
\hline 6 & $\begin{array}{l}\text { To share } \\
\text { knowledge, } \\
\text { interesting articles, } \\
\text { how-to-do tips }\end{array}$ & 0 & 0 & 6.67 & 8 & $\begin{array}{l}33.3 \\
3 \\
\end{array}$ & 40 & $\begin{array}{l}46.6 \\
7 \\
\end{array}$ & 56 & $\begin{array}{l}13.3 \\
3 \\
\end{array}$ & 16 & 120 & $\begin{array}{l}3.6 \\
7 \\
\end{array}$ & $\begin{array}{l}0.9 \\
2 \\
\end{array}$ \\
\hline 7 & $\begin{array}{lll}\text { To share } & \text { on } \\
\text { passion/hobby } & \end{array}$ & 0 & 0 & 0 & 0 & 40 & 48 & 60 & 72 & 0 & 0 & 120 & $\begin{array}{l}3.6 \\
0\end{array}$ & $\begin{array}{l}0.9 \\
3\end{array}$ \\
\hline 8 & $\begin{array}{l}\text { To share latest } \\
\text { news }\end{array}$ & 6.67 & 8 & $\begin{array}{l}20.0 \\
0\end{array}$ & 24 & $\begin{array}{l}26.6 \\
7\end{array}$ & 32 & $\begin{array}{l}33.3 \\
3\end{array}$ & 40 & $\begin{array}{l}13.3 \\
3\end{array}$ & 16 & 120 & $\begin{array}{l}3.2 \\
7\end{array}$ & $\begin{array}{l}0.9 \\
3\end{array}$ \\
\hline 9 & $\begin{array}{l}\text { To share religious } \\
\text { verses, } \\
\text { pictures etc }\end{array}$ & $\begin{array}{l}66.6 \\
7 \\
\end{array}$ & 80 & $\begin{array}{l}20.0 \\
0\end{array}$ & 24 & $\begin{array}{l}13.3 \\
3\end{array}$ & 16 & 0.00 & 0 & 0.00 & 0 & 120 & $\begin{array}{l}1.4 \\
7 \\
\end{array}$ & $\begin{array}{l}0.9 \\
7\end{array}$ \\
\hline 10 & $\begin{array}{l}\text { To update all the } \\
\text { whereabouts }\end{array}$ & $\begin{array}{l}20.0 \\
0 \\
\end{array}$ & 24 & $\begin{array}{l}28.3 \\
3 \\
\end{array}$ & 34 & $\begin{array}{l}20.0 \\
0 \\
\end{array}$ & 24 & $\begin{array}{l}25.0 \\
0 \\
\end{array}$ & 30 & 6.67 & 8 & 120 & $\begin{array}{l}2.7 \\
0 \\
\end{array}$ & $\begin{array}{l}0.9 \\
5\end{array}$ \\
\hline 11 & $\begin{array}{lr}\begin{array}{l}\text { To share } \\
\text { friend's } \\
\text { message }\end{array} & \text { status } \\
\end{array}$ & $\begin{array}{l}33.3 \\
3 \\
\end{array}$ & 40 & $\begin{array}{l}46.6 \\
7 \\
\end{array}$ & 56 & $\begin{array}{l}20.0 \\
0 \\
\end{array}$ & 24 & 0.00 & 0 & 0.00 & 0 & 120 & $\begin{array}{l}1.8 \\
7\end{array}$ & $\begin{array}{l}0.9 \\
6\end{array}$ \\
\hline 12 & $\begin{array}{l}\text { To share their } \\
\text { Selfie photos }\end{array}$ & 6.67 & 8 & 37.5 & 45 & $\begin{array}{l}20.0 \\
0 \\
\end{array}$ & 24 & $\begin{array}{l}20.8 \\
3 \\
\end{array}$ & 25 & $\begin{array}{l}15.0 \\
0 \\
\end{array}$ & 18 & 120 & 3.0 & $\begin{array}{l}0.9 \\
4\end{array}$ \\
\hline 13 & $\begin{array}{lr}\text { To } & \text { share } \\
\text { inspirational quotes } \\
\text { from great } \\
\text { philosophers }\end{array}$ & 6.67 & 8 & $\begin{array}{l}40.8 \\
3 \\
\end{array}$ & 49 & $\begin{array}{l}26.6 \\
7\end{array}$ & 32 & $\begin{array}{l}19.1 \\
7\end{array}$ & 23 & 6.67 & 8 & 120 & $\begin{array}{l}2.7 \\
8 \\
\end{array}$ & $\begin{array}{l}0.9 \\
4\end{array}$ \\
\hline 14 & $\begin{array}{l}\text { To share pictures of } \\
\text { pets or animals }\end{array}$ & $\begin{array}{l}40.0 \\
0\end{array}$ & 48 & $\begin{array}{l}46.6 \\
7\end{array}$ & 56 & $\begin{array}{l}13.3 \\
3\end{array}$ & 16 & 0.00 & 0 & 0.00 & 0 & 120 & $\begin{array}{l}1.7 \\
3\end{array}$ & $\begin{array}{l}0.9 \\
7\end{array}$ \\
\hline 15 & $\begin{array}{l}\text { To share any } \\
\text { interesting posts }\end{array}$ & 0.00 & 0 & $\begin{array}{l}13.3 \\
3\end{array}$ & 16 & $\begin{array}{l}53.3 \\
3\end{array}$ & 64 & $\begin{array}{l}13.3 \\
3\end{array}$ & 16 & $\begin{array}{l}20.0 \\
0\end{array}$ & 24 & 120 & $\begin{array}{l}3.4 \\
0\end{array}$ & $\begin{array}{l}0.9 \\
3\end{array}$ \\
\hline 16 & $\begin{array}{l}\text { To wish friends for } \\
\text { birthdays, wedding }\end{array}$ & 0.00 & 0 & 0.00 & 0 & 6.67 & 8 & $\begin{array}{l}73.3 \\
3\end{array}$ & 88 & $\begin{array}{l}20.0 \\
0\end{array}$ & 24 & 120 & $\begin{array}{l}4.1 \\
3\end{array}$ & $\begin{array}{l}0.9 \\
1\end{array}$ \\
\hline
\end{tabular}


A Study on the Uses of Social Networking Sites on Young Adults to Infer On the Different...

\begin{tabular}{|c|c|c|c|c|c|c|c|c|c|c|c|c|c|c|}
\hline & $\begin{array}{ll}\text { or } & \text { work } \\
\text { anniversaries } & \\
\end{array}$ & & & & & & & & & & & & & \\
\hline 17 & $\begin{array}{l}\text { To post jokes etc to } \\
\text { grab the attention } \\
\text { of others }\end{array}$ & $\begin{array}{l}18.3 \\
3\end{array}$ & 22 & $\begin{array}{l}30.0 \\
0\end{array}$ & 36 & & 16 & $\begin{array}{l}30.0 \\
0\end{array}$ & 36 & 8.33 & 10 & 120 & $\begin{array}{l}2.8 \\
0\end{array}$ & $\begin{array}{l}0.9 \\
4\end{array}$ \\
\hline 18 & $\begin{array}{l}\text { Always post in } \\
\text { vernacular } \\
\text { languages }\end{array}$ & $\begin{array}{l}66.6 \\
7\end{array}$ & 80 & $\begin{array}{l}33.3 \\
3\end{array}$ & 40 & 0.00 & 0 & 0.00 & 0 & 0.00 & 0 & 120 & $\begin{array}{l}1.3 \\
3\end{array}$ & $\begin{array}{l}0.9 \\
8\end{array}$ \\
\hline 19 & $\begin{array}{l}\text { To like all the post } \\
\text { of friends or } \\
\text { favourite stars/ } \\
\text { brands }\end{array}$ & $\begin{array}{l}20.0 \\
0\end{array}$ & 24 & $\begin{array}{l}13.3 \\
3\end{array}$ & 16 & $\begin{array}{l}33.3 \\
3\end{array}$ & 40 & $\begin{array}{l}33.3 \\
3\end{array}$ & 40 & 0.00 & 0 & 120 & $\begin{array}{l}2.8 \\
0\end{array}$ & $\begin{array}{l}0.9 \\
4\end{array}$ \\
\hline 20 & $\begin{array}{lr}\text { To respond to } \\
\text { every } & \text { status } \\
\text { message, picture, } \\
\text { or video friends } \\
\text { shares }\end{array}$ & $\begin{array}{l}40.0 \\
0\end{array}$ & 48 & $\begin{array}{l}33.3 \\
3\end{array}$ & 40 & $\begin{array}{l}26.6 \\
7\end{array}$ & 32 & 0.00 & 0 & 0.00 & 0 & 120 & $\begin{array}{l}1.8 \\
7\end{array}$ & $\begin{array}{l}0.9 \\
6\end{array}$ \\
\hline 21 & $\begin{array}{l}\text { To read all the } \\
\text { friends messages, } \\
\text { but never respond }\end{array}$ & $\begin{array}{l}26.6 \\
7\end{array}$ & 32 & $\begin{array}{l}33.3 \\
3\end{array}$ & 40 & $\begin{array}{l}33.3 \\
3\end{array}$ & 40 & 6.67 & 8 & 0.00 & 0 & 120 & $\begin{array}{l}2.2 \\
0\end{array}$ & $\begin{array}{l}0.9 \\
6\end{array}$ \\
\hline 22 & $\begin{array}{l}\text { To add/make many } \\
\text { friends or followers }\end{array}$ & $\begin{array}{l}14.1 \\
7\end{array}$ & 17 & $\begin{array}{l}30.0 \\
0\end{array}$ & 36 & $\begin{array}{l}26.6 \\
7\end{array}$ & 32 & $\begin{array}{l}16.6 \\
7\end{array}$ & 20 & 12.5 & 15 & 120 & $\begin{array}{l}2.8 \\
3\end{array}$ & $\begin{array}{l}0.9 \\
4\end{array}$ \\
\hline 23 & $\begin{array}{l}\text { To play games on } \\
\text { Facebook } \\
\text { (Farmville, Candy } \\
\text { Crush Saga) }\end{array}$ & 27.5 & 33 & $\begin{array}{l}13.3 \\
3\end{array}$ & 16 & & 30 & $\begin{array}{l}13.3 \\
3\end{array}$ & 16 & $\begin{array}{l}20.8 \\
3\end{array}$ & 25 & 120 & $\begin{array}{l}2.8 \\
7\end{array}$ & $\begin{array}{l}0.9 \\
4\end{array}$ \\
\hline 24 & $\begin{array}{l}\text { To promote their } \\
\text { company, favourite } \\
\text { actor, music bands, } \\
\text { brands, etc. }\end{array}$ & $\begin{array}{l}33.3 \\
3\end{array}$ & 40 & $\begin{array}{l}46.6 \\
7\end{array}$ & 56 & & 16 & 6.67 & 8 & 0.00 & 0 & 120 & $\begin{array}{l}1.9 \\
3\end{array}$ & $\begin{array}{l}0.9 \\
6\end{array}$ \\
\hline 25 & $\begin{array}{l}\text { To follow their } \\
\text { favourite actors/ } \\
\text { actresses/music } \\
\text { bands/ brands etc }\end{array}$ & $\begin{array}{l}46.6 \\
7\end{array}$ & 56 & $\begin{array}{l}33.3 \\
3\end{array}$ & 40 & & 24 & 0.00 & 0 & 0.00 & 0 & 120 & $\begin{array}{l}1.7 \\
3\end{array}$ & $\begin{array}{l}0.9 \\
7\end{array}$ \\
\hline 26 & $\begin{array}{l}\text { To look for } \\
\text { attractive dates or } \\
\text { opposite rex } \\
\text { members (dating) }\end{array}$ & $\begin{array}{l}73.3 \\
3\end{array}$ & 88 & $\begin{array}{l}20.0 \\
0\end{array}$ & 24 & 6.67 & 8 & 0.00 & 0 & 0.00 & 0 & 120 & $\begin{array}{l}1.3 \\
3\end{array}$ & $\begin{array}{l}0.9 \\
8\end{array}$ \\
\hline 27 & $\begin{array}{l}\text { Use Hashes in all } \\
\text { the posts }\end{array}$ & $\begin{array}{l}16.6 \\
7\end{array}$ & 20 & $\begin{array}{l}38.3 \\
3\end{array}$ & 46 & & 16 & $\begin{array}{l}23.3 \\
3\end{array}$ & 28 & 8.33 & 10 & 120 & $\begin{array}{l}2.6 \\
8\end{array}$ & $\begin{array}{l}0.9 \\
5\end{array}$ \\
\hline 28 & $\begin{array}{l}\text { Tag themselves or } \\
\text { friends in all the } \\
\text { photos }\end{array}$ & $\begin{array}{l}26.6 \\
7\end{array}$ & 32 & & 25 & $\begin{array}{l}26.6 \\
7\end{array}$ & 32 & $\begin{array}{l}19.1 \\
7\end{array}$ & 23 & & 8 & 120 & $\begin{array}{l}2.5 \\
8\end{array}$ & $\begin{array}{l}0.9 \\
5\end{array}$ \\
\hline 29 & $\begin{array}{l}\text { To look for jobs/ } \\
\text { career orientation }\end{array}$ & $\begin{array}{l}18.3 \\
3\end{array}$ & 22 & $\begin{array}{l}20.0 \\
0\end{array}$ & 24 & $\begin{array}{l}40.0 \\
0\end{array}$ & 48 & $\begin{array}{l}13.3 \\
3\end{array}$ & 16 & 8.33 & 10 & 120 & $\begin{array}{l}2.7 \\
3\end{array}$ & $\begin{array}{l}0.9 \\
5\end{array}$ \\
\hline 30 & $\begin{array}{ll}\text { For } & \text { academic } \\
\text { purpose }\end{array}$ & $\begin{array}{l}25.0 \\
0\end{array}$ & 30 & $\begin{array}{l}20.0 \\
0\end{array}$ & 24 & $\begin{array}{l}40.0 \\
0\end{array}$ & 48 & 6.67 & 8 & 8.33 & 10 & 120 & $\begin{array}{l}2.5 \\
3\end{array}$ & $\begin{array}{l}0.9 \\
5\end{array}$ \\
\hline 31 & $\begin{array}{l}\text { To support \& } \\
\text { propagate } \\
\text { party's }\end{array}$ & $\begin{array}{l}53.3 \\
3\end{array}$ & 64 & $\begin{array}{l}33.3 \\
3\end{array}$ & 40 & 6.67 & 8 & 6.67 & 8 & 0.00 & 0 & 120 & $\begin{array}{l}1.6 \\
7\end{array}$ & $\begin{array}{l}0.9 \\
7\end{array}$ \\
\hline 32 & $\begin{array}{lr}\text { To steal friends' } \\
\text { personal details/ } \\
\text { contact information }\end{array}$ & $\begin{array}{l}93.3 \\
3\end{array}$ & $\begin{array}{l}11 \\
2\end{array}$ & 0.00 & 0 & 6.67 & 8 & 0.00 & 0 & 0.00 & 0 & 120 & $\begin{array}{l}1.1 \\
3\end{array}$ & $\begin{array}{l}0.9 \\
8\end{array}$ \\
\hline
\end{tabular}

As seen from TABLE 1, the mean scores ranging from 1 to 5 clearly indicate that majority of the sample used SNSs mainly to wish their friends for birthdays, wedding or work anniversaries (4.13); to find old friends, new friends, colleagues (3.73); to share knowledge (3.67); to share their passion/hobby (3.60); to check 
what their friends have posted (3.60); to chat with friends or family (3.47); to share interesting posts (3.40); to share latest news (3.27); to share their Selfie photos (3.0); to build new contacts or make new friends (2.87); to play games on Facebook; (2.87); to add or make many friends or followers (2.83); to like all the posts of their friends or their favourite stars/brands (2.80); to post jokes etc to grab the attention of others (2.80); to share inspirational quotes (2.78); to look for jobs/ career orientation (2.73); to update all their whereabouts (2.70); Use Hashes in all the posts (2.68); to create new content (like blogs, videos) and share (2.67); to Tag themselves or friends in all the photos (2.58); for academic purposes (2.53).

Also the respondents used SNSs to read all their friends' status messages (2.20); to promote their company, favourite actor, music bands, brands, etc (1.93); to share friend's status message (1.87); to respond to every status message, picture, or video their friends' share (1.87); to share pictures of pets or animals (1.73); to follow favourite actors/actresses/music bands/brands etc (1.73); to support \& propagate their favourite political party's views, ideals (1.67); to share religious verses, views, pictures etc (1.47); to always post in vernacular languages (1.33); to look for attractive dates (dating) (1.33); and to steal their friends personal details/contact information (0.98).

From the above mean scores, it can be deduced that majority of the sample used SNSs to wish their friends for birthdays, wedding or work anniversaries (4.13); to find old friends, new friends, colleagues (3.73); to share knowledge (3.67); to share their passion/hobby (3.60); to check what their friends have posted (3.60); to chat with friends/family (3.47); while very few use it for stealing their friends personal details/contact information (0.98).

The following are the major findings of the study:

\section{Major Findings}

1. Facebook, LinkedIn, Twitter and Google+ are the frequently used SNSs among young adults in Bangalore.

2. Facebook [66.67\% $(\mathrm{n}=80)]$ was the favourite Social Networking Site among young adults in Bangalore.

3. The most popular uses of SNSs are: to wish their friends for birthdays, wedding or work anniversaries; to find old friends, new friends, colleagues; to share knowledge; to share their passion/hobby; to check what their friends have posted; to chat with friends or family; to share interesting posts; to share latest news; to share their Selfie photos; to build new contacts or make new friends; to play games on Facebook; to add or make many friends or followers; to like all the posts of their friends or their favourite stars/brands; to post jokes etc to grab the attention of others; to share inspirational quotes; to look for jobs/ career orientation; to update all their whereabouts; Use Hashes in all the posts; to create new content (like blogs, videos) and share; to Tag themselves or friends in all the photos; for academic purposes. Also the respondents used SNSs to read all their friends' status messages; to promote their company, favourite actor, music bands, brands, etc; to share friend's status message; to respond to every status message, picture, or video their friends' share; to share pictures of pets or animals; to follow favourite actors/actresses/music bands/brands etc; to support \& propagate their favourite political party's views, ideals; to share religious verses, views, pictures etc; to always post in vernacular languages; to look for attractive dates (dating) and to steal their friends personal details/contact information.

4. The different types of SNSs users identified are: Networkers, Chatters, Buddy's Info Seekers, Content Makers, Professors, Hobby Vicars, Reporters, Preachers, Frequent Communicators, Status Stealers, SelfBroadcasters, Philosophers, Pet Lovers, Attractive Posters, Best Wishers, Attention Grabbers, Vernacular Posters, Like Likers, Responders, Silent Observers, Social Stars, Players, Endorsers, Dedicated Followers, Daters, Feature Lovers, Career Seekers, Learners, Political Campaigners, and Info Pilfers.

\section{Conclusion}

The study elicits the role of SNSs in the social life of young adults in Bangalore. The findings of the study clearly depict the current scenario on the divergent uses of SNSs in the daily lives of the young adults in Bangalore City.

The study found that Facebook, LinkedIn, Twitter and Google+ were the most frequently used SNSs among young adults in Bangalore. Also, Facebook [66.67\% ( $\mathrm{n}=80)$ ], world's number one social networking site, was the favourite Social Networking Site, though many other SNSs were available freely.

The divergent uses of SNSs make SNSs as an interactive platform for interpersonal connectivity and social enhancement through social communication. The findings of the study have found 32 detailed uses of SNSs to describe the different ways in which people use SNSs in their daily lives. With majority of the sample using SNSs regularly, the following 21 uses of SNSs were considered as the main uses, they are: to wish their friends for birthdays, wedding or work anniversaries; to find old friends, new friends, colleagues; to share knowledge; to share their passion/hobby; to check what their friends have posted; to chat with friends or family; to share interesting posts; to share latest news; to share their Selfie photos; to build new contacts or make new friends; to play games on Facebook; to add or make many friends or followers; to like all the posts of their 
A Study on the Uses of Social Networking Sites on Young Adults to Infer On the Different...

friends or their favourite stars/brands; to post jokes etc to grab the attention of others; to share inspirational quotes; to look for jobs/ career orientation; to update all their whereabouts; Use Hashes in all the posts; to create new content (like blogs, videos) and share; to Tag themselves or friends in all the photos and for academic purposes. And the following 11 uses of SNSs were used sometimes or rarely by the sample: to read all their friends' status messages; to promote their company, favourite actor, music bands, brands, etc; to share friend's status message; to respond to every status message, picture, or video their friends' share; to share pictures of pets or animals; to follow favourite actors/actresses/music bands/brands etc; to support \& propagate their favourite political party's views, ideals; to share religious verses, views, pictures etc; to always post in vernacular languages; to look for attractive dates (dating); and to steal their friends personal details/contact information. All the 32 uses of SNSs identified are important as the usage pattern on the uses of SNSs are volatile, hence a study conducted after a certain time frame may show different uses as the main uses of SNSs. Thus, the divergent uses of SNSs in the present study reinforce SNSs as the preferred choice of communication tool, especially for social communication in urban areas.

The study identified and categorised different types of SNSs users in Bangalore city based on the uses of SNSs. The 30 different types of SNSs users identified are: Networkers, Chatters, Buddy's Info Seekers, Content Makers, Professors, Hobby Vicars, Reporters, Preachers, Frequent Communicators, Status Stealers, Self-Broadcasters, Philosophers, Pet Lovers, Attractive Posters, Best Wishers, Attention Grabbers, Vernacular Posters, Like Likers, Responders, Silent Observers, Social Stars, Players, Endorsers, Dedicated Followers, Daters, Feature Lovers, Career Seekers, Learners, Political Campaigners, and Info Pilfers. Since, SNSs are multi-purpose sites and divergent in nature, their users can't be classified broadly. So, this study has classified them in detail, into 30 different types of users. Also, with newer features available freely in almost all the SNSs, users can choose and use these innovative features to increase their uses of SNSs based on their personal requirements. Hence, users will fall into more than one category of users identified here and may create newer categories in the future.

The different types of users identified here can help marketing professionals to enhance their success rate on digital marketing campaigns, by fine tuning their campaigns. Also, the different types of users identified here can help in customizing the existing or yet-to-be launched SNSs' new features or designs based on the different user types and usage patterns.

The study has added to the existing body of literature or knowledge by identifying a broader classification of 30 types of SNSs users.

\section{Limitations and Future Research}

The research study has identified 32 uses of SNSs, frequently used SNSs, favorite SNSs of young adults in Bangalore city and 30 different types of SNSs users in Bangalore.

This study also has its limitations, which might affect the generalisability of its findings. The generalisability of the present study is limited, as the sample size was limited to Bangalore city only.

Thus, future research can be conducted on respondents across India or even the world. Also, crossnational or cross-cultural studies can be conducted to see if the uses of SNSs are the same between 2 different countries or their socio-economic factors contribute to the discrepancy. Also, future studies can concentrate on the factors contributing to each of these SNSs user types identified.

These SNSs uses and user types identified are constantly changing over a period of time. The usage pattern and features of the SNSs are changing with the launch of innovative features and uses of SNSs. Hence, long term studies can be conducted in the future, as both user patterns and features of SNSs evolve over a period of time.

\section{Bibliography}

[1] Abro, M., Zhenfang, L., Chhachhar, A.R., Gillani, S.A.H. Social Networking Sites' Usage Trends and Adoption Among University Students: A Descriptive Analysis, New Media and Mass Communication, Vol.23, 2014.

[2] Al kindi, Salim Said Ali and Saadat M. Alhashmi. Use of Social Networking Sites Among Shinas College of Technology Students in Oman, Journal of Information \& Knowledge Management, Vol. 11, No. 1, 2012.

[3] Bernoff, Josh \& Li, Charlene. Marketing in the Groundswell, Forrester Research Inc., Harvard Business Press, 2009.

[4] Boyd, D.M. "Why Youth (Heart) Social Network Sites: The Role of Networked Publics in Teenage Social Life." MacArthur Foundation Series on Digital Learning - Youth, Identity, and Digital Media Volume (ed. David Buckingham). Cambridge, MA: MIT Press, 2007.

[5] Brandtzæg, P.B. and Heim, J. (2011) 'A typology of social networking sites users', Int. J. Web Based Communities, Vol. 7, No. 1, pp.28-51.

[6] Cheung, Christy M.K., Pui-Yee Chiu, Matthew K.O. Lee. Online social networks: Why do students use Facebook? Computers in Human Behavior 27 (2011) 1337-1343, 2011.

[7] Dodaro, Melonie. 10 Types of Social Media Users, topdogsocialmedia.com, 7 Nov., 2013.

[8] Haneefa, M. K. and Sumitha E. Perception and Use of Social Networking Sites by the Students of Calicut University, DESIDOC Journal of Library \& Information Technology, Vol. 31, No. 4, July 2011, pp. 295-301, 2011.

[9] Kawaski, Guy (2009). The Six Twitter Types, open forum, 11 December, 2009. 
[10] Kumar, Neeraj. User Perception and Use of Social Networking Sites by Sikkim University Students, 8th Convention PLANNER2012, Sikkim University, Gangtok, March 01-03, 2012 @ INFLIBNET Centre, Ahmedabad, 2012.

[11] Madhusudhan, M. Use of social networking sites by research scholars of the University of Delhi: A study, The International Information \& Library Review, Volume 44, Issue 2, June 2012, Pages 100-113, 2012.

[12] Male, Bianca (2009). The 6 People You'll Meet On Twitter, Business Insider, 16 December, 2009.

[13] Manjunatha S. The Usage of Social Networking sites Among the College Students in India, International Research Journal of Social Science, Vol. 2(5), 15-21, May, 2013

[14] Mazman, G. \& Usluel Y.K. Gender Differences in Using Social Networks, The Turkish Online Journal of Educational Technology - April 2011, volume 10 Issue2, 2011.

[15] Mirani, M. Ali. Motives for Students Using Social Networking Sites: Findings from Sukkur, Pakistan, 2nd International Conference on Economics, Business and Management IPEDR vol.22 (2011) IACSIT Press, Singapore, 2011.

[16] Muscanell, N.L., Guadagno, R.E. Make new friends or keep the old: Gender and personality differences in social networking use, Computers in Human Behavior 28 (2012) 107-112, 2012.

[17] OFCOM (2008) 'Social networking. a quantitative and qualitative research report into attitudes, behaviours and use', Office of Communication, London.

[18] Pempek, T., Yermolayeva, Y., \& Calvert, S. College students' social networking experiences on Facebook, Journal of Applied Developmental Psychology, 30(3). 227-238, 2009.

[19] Pierce, Tamyra A. Talking to Strangers on MySpace: Teens' Use of Internet Social Networking Sites, Journal of Media Psychology, Volume 11, No. 3, Fall 2006.

[20] Saleem Alhabash, Hyojung Park, Anastasia Kononova, Yi-hsuan Chiang and Kevin Wise. Exploring the Motivations of Facebook Use in Taiwan, Cyber Psychology, Behavior and Socila Networking. Volume 15, Number 6, 2012.

[21] Singh, KP and Malkeet Singh Gill. Use of Social Networking Sites by the Research Scholars: A Study of Guru Nanak Dev University, Amritsar. Library Herald, Vol. 49 No. 3, September 2011.

[22] Smith, A. Why Americans use social media, Pew Internet \& American Life Project, 2011.

[23] Subrahmanyam, K., Stephanie M. Reich, Natalia Waechter, Guadalupe Espinoza. Online and offline social networks: Use of social networking sites by emerging adults, Journal of Applied Developmental Psychology 29 (2008) 420-433, 2008.

[24] Swidan, A., Al-Shalabi, H., Jwaifell, M., Awajan A. and Alrabea, A. The Intensity and the Factors Affecting the Use of Social Network Sites Among the Students of Jordanian Universities, IJCSI International Journal of Computer Science Issues, Vol. 10, Issue 1, No 3, January, 2013.

[25] Young People and Social Networking Services: A Childnet International Research Report, 2008.

\section{Websites}

[1] Anderson Analytics. Not All Social Network Users Alike - Four Types of LinkedIn Users - Which Type are you? [online] http://www.andersonanalytics.com/index.php?mact=News, cntnt01, detail, $0 \&$ cntnt01 articleid=52\&cntnt01 origid=16\&cntnt01detailte mplate $=$ newsdetail.tpl\&cntnt01dateformat $=\% 25 \mathrm{~m} . \% 25 \mathrm{~d} . \% 25 \mathrm{Y} \& \mathrm{cntnt} 01$ returnid $=46$ (5 November, 2008)

[2] Bernoff, Social Technographics Defined. [online] http://www.slideshare.net/jbernoff/social-technographics-explained (18 March, 2008)

[3] Bernoff, Social Technographics Defined. [online] http://www.slideshare.net/jbernoff/social-technographics-defined-2010 (27 July, 2010)

[4] Casti, Taylor. The 9 Types of Facebook Users [online] http://mashable.com/2013/07/25/types-facebook-users/ (25 July, 2013)

[5] Chan, Adrian. Social Media Personality Types [online] http://www.slideshare.net/gravity $7 /$ gravity 7 -personality-types-12-04-08presentation (5 December, 2008)

[6] Dial, Minter. Presentation the 7 archetypes of Twitter users, [online] http://themyndset.com/?attachment_id=12338; http://themyndset.com/2013/10/7-archetypes-of-twitter-users-accounts-to-follow/ (28 October, 2013)

[7] Dodarao, Melonie. 10 types of Social media users [online] http://topdogsocialmedia.com/10-types-of-social-media-users/ (7 Nov., 2013)

[8] Doozyden. 25 types of Facebook users you encounter,Are you one of them or have someone in your friendlist? [Online] http://doozyden.com/25-types-of-facebook-users-you-encounterare-you-one-of-them-or-have-someone-in-your-friendlist/ (12 July, 2014)

[9] Faktor, Steve. The 10 Types of Twitterers and How to Tame Their Tweets. [online] http://www.forbes.com/sites/stevefaktor/2013/01/04/the-10-types-of-twitterers-and-how-to-tame-their-tweets-twitter-users/ (4 January, 2013)

[10] Ibnlive. 16 types of Facebook users. What's your type? [online] http://ibnlive.in.com/news/16-types-of-facebook-users-whats-yourtype/434797-11.html (18 Nov., 2013)

[11] Kawaski, Guy. The Six Twitter Types [online] https://www.americanexpress.com/us/small-business/openforum/articles/the-sixtwitter-types-1/ (11 December, 2009)

[12] Male, Bianca. The 6 People You'll Meet On Twitter [online] http://www.businessinsider.com/guy-kawasakis-six-twitter-types2009-12?IR=T

[13] Nielsen, J. The 90-9-1 Rule for Participation Inequality in Social Media and Online Communities [online] http://www.nngroup.com/articles/participation-inequality/ (9 October, 2006)

[14] Pickering, Ben. 10 Types of Twitter Users [online] http://www.huffingtonpost.com/ben-pickering/types-of-twitterusers b 4208702.html (23 January, 2014) 